Фроленкова Н. А. ${ }^{[1 ;}$ ORCID iD 0000-0003-4553-9547], к.е.н, доцент,

Ступницька М. О. ${ }^{[1]}$, здобувач вищої освіти другого (магістерського) рівня

${ }^{1}$ Національний університет водного господарства та природокористування, м. Рівне

\title{
ОСОБЛИВОСТІ ФОРМУВАННЯ ІНФРАСТРУКТУРИ РИНКУ ОСВІТИ ДОРОСЛИХ В УКРАЇНІ
}

У статті визначено основні передумови реформування системи освіти в напрямку впровадження концепції неперервної освіти та освіти дорослих. Визначені особливості освіти дорослих, що впливає на формування інфраструктури ринку освітніх послуг, вибір форм та методів навчання. Виокремлені основні завдання щодо формування ринку освіти дорослих в Україні.

Ключові слова: неперервна освіта; освіта дорослих; інфраструктура; ринок освітніх послуг; завдання; особливості.

Постановка проблеми. Необхідність формування сучасних компетенцій в усіх сферах життя сьогодні зумовлює перехід від масової моделі здобуття освіти до індивідуально-орієнтованої. Розвиток технологій і скорочення життєвого циклу професій призвели до старіння класичної моделі освіти «школа - вищий навчальний заклад». Їй на зміну прийшла концепція неперервного навчання. Завдання неперервної освіти полягає не тільки в збагаченні людини новими знаннями, але і в збереженні їі професійної компетентності протягом усього життя.

На фоні швидких і різноспрямованих змін зростає роль знань, умінь і навичок усіх членів суспільства. Економічно розвинуті країни інтенсивно розвивають і удосконалюють систему освіти дорослих, як елемент освіти впродовж життя, що забезпечує успішний розвиток суспільства. Освіта дорослих - це окремий напрямок, що забезпечує задоволення освітніх потреб осіб, зайнятих самостійною професійною діяльністю. Необхідність освіти дорослих обумовлена динамікою соціального, економічного, культурного і науковотехнічного прогресу, змінами в змісті і характері праці і суспільної діяльності людей, збільшенням вільного часу i, таким чином, можливостей його раціонального використання. В даний час значення такої освіти посилюється, оскільки відбувається структурна 
перебудова економіки, що обумовлює необхідність перекваліфікації та перенавчання значного числа осіб працездатного віку.

Невирішена раніше частина загальної проблеми. Поки неперервна освіта все ще сприймається як надбудова - додаткове навчання в тих випадках, коли не вистачає основного. Але в новій економіці освіта буде розглядатись як «пожиттєвий» процес, який стане основним двигуном кар'єри і передумовою можливості множинних професійних сценаріїв протягом усього життя. Це визначає головну зміну сьогоднішнього часу - запит на індивідуалізацію освітніх траєкторій. Набір необхідних конкретній дорослій людині компетенцій повинен обирати не навчальний заклад, а кожен для себе самостійно. Змінюється і роль викладача він уже не просто транслятор знань, а дослідник, консультант, ментор, керівник проєктів.

В Україні традиційно освіту дорослих прийнято розглядати переважно як додаткову професійну освіту. В останні роки ініціативи, проєкти, ідеї, пов'язані 3 навчанням дорослих, починають розвиватися на місцях, в регіонах. Однак усі існуючі в країні форми навчання дорослих організаційно і адміністративно перебувають у різному підпорядкуванні і не об'єднані єдиною державною політикою, відповідними управлінськими та координуючими структурами, теоретичними і науково-методичними принципами навчання.

Цілі дослідження. Отже, зростаюче різноманіття пізнавальних та інформаційних запитів різних верств населення сьогодні вже неможливо задовольнити в рамках існуючих форм традиційної освіти. Загострюється проблема невідповідності сформованої системи освіти новим потребам суспільства та людини. Це вимагає іншого підходу до організації масової освітньої діяльності дорослих освіта повинна відповідати різноманітним інтересам і можливостям громадян, органічно вписуватися в їх спосіб життя, враховувати специфіку запитів контингенту і навіть певних груп населення.

Основні результати дослідження. Інфраструктура ринку освітніх послуг для дорослих повинна формуватись з урахуванням особливостей і потреб, психофізіологічних характеристик, досвіду здобувачів. Особливістю навчання дорослих людей $€$ те, що воно має здійснюватися з урахуванням їх вікових, соціально-психологічних, національних та інших особливостей, що необхідно враховувати при формуванні освітньої моделі навчання:

1. Усвідомлене ставлення дорослих здобувачів до процесу свого навчання; потреба в самостійності; потреба в осмисленості навчання (для вирішення важливої проблеми і досягнення 
конкретної мети), що забезпечує мотивацію. Як правило, дорослі люди хочуть вчитися, якщо вони бачать необхідність навчання $\mathrm{i}$ можливість застосувати його результати для поліпшення своєї діяльності.

2. Провідну роль в процесі навчання грає не викладач, функцією якого $\epsilon$ надання допомоги студенту у виявленні, систематизації, формалізації особистого досвіду останнього, коригування та поповнення його знань. В освіті дорослих завдання викладача - організувати навчальний процес так, щоб слухачі ставали «співавторами» власного навчання.

3. Зміна пріоритетності методів навчання. Замість лекційних, андрагогіка передбачає переважно практичні заняття, часто експериментального характеру, дискусії, ділові ігри, кейси, вирішення конкретних виробничих завдань і проблем. Крім того, змінюється підхід до отримання теоретичних знань. На перше місце виходять дисципліни, що містять інтегрований матеріал по декільком суміжним областям знань, наприклад, управління проєктами. Останнім часом все більшою популярністю користуються активні методи навчання дорослих: презентації, семінари, ділові та рольові ігри, бізнес-тренінги, воркшопи, кейси, дискусії в малих групах, моделювання та виконання проєктів, навчання дією і т.д. Вони передбачають варіативність форм навчальної діяльності, використання різноманітних форм організації групової роботи, динамічну зміну видів діяльності.

4. Для максимально ефективного досягнення цілей андрагогіки доцільним $є$ поділ дорослих по різних вікових категоріях. Соціальна наука виділяє три вікові категорії: до 25 років, від 25 до 45 років, понад 45 років. Дорослі освоюють нові знання і навички з різною швидкістю, тому потребують індивідуалізації навчання, підвищення самооцінки і почуття власної гідності. Тому для кожної категорії необхідно встановити необхідні цілі, підходи, методи, терміни і ритм навчання, визначити взаємодію працівників, що відносяться до різних категорій.

5. Складність та перепони у процесі навчання, що пов'язані з:

- неготовністю до змін і психологічними причинами (занепокоєнням про свій авторитет, страхом виглядати некомпетентним в очах оточуючих, невідповідністю власного образу «солідної людини» і ролі учня). Дорослий усвідомлює себе самостійною, самокерованою особистістю і критично ставиться до будь-яких спроб керувати ним, навіть якщо вголос цього не висловлює; 
- накопиченим запасом життєвого, соціального і професійного досвіду, який формує його світогляд і з точки зору якого він оцінює будь-яку інформацію, що надходить;

- впливом старої педагогічної парадигми з усіма властивими їй недоліками: догматичний тип навчання, лекційна форма проведення занять, відрив теорії від життя, переважання технократичного мислення, орієнтація на засвоєння готових знань;

- вплив на процес навчання професійних, соціальних, побутових і тимчасових факторів.

6. Переважно прагнення до активної участі в процесі навчання, привнесення в навчальні ситуації власного досвіду і своїх життєвих цінностей, співвіднесення навчальних ситуацій зі своїми цілями і завданнями.

7. Практична спрямованість щодо навчання, прагнення до застосування отриманих знань, умінь і навичок в професійній діяльності.

Такі особливості не можуть не впливати на модель формування інфраструктури освіти дорослих, на вибір методів, форм, технологій їх навчання.

На сучасному етапі розвитку суспільства у всіх регіонах України створені освітні центри для різних категорій дорослих, більшість яких взаємодіє та співпрацює з іншими навчальними закладами для молоді, громадськими та іншими організаціями (рис. 1).

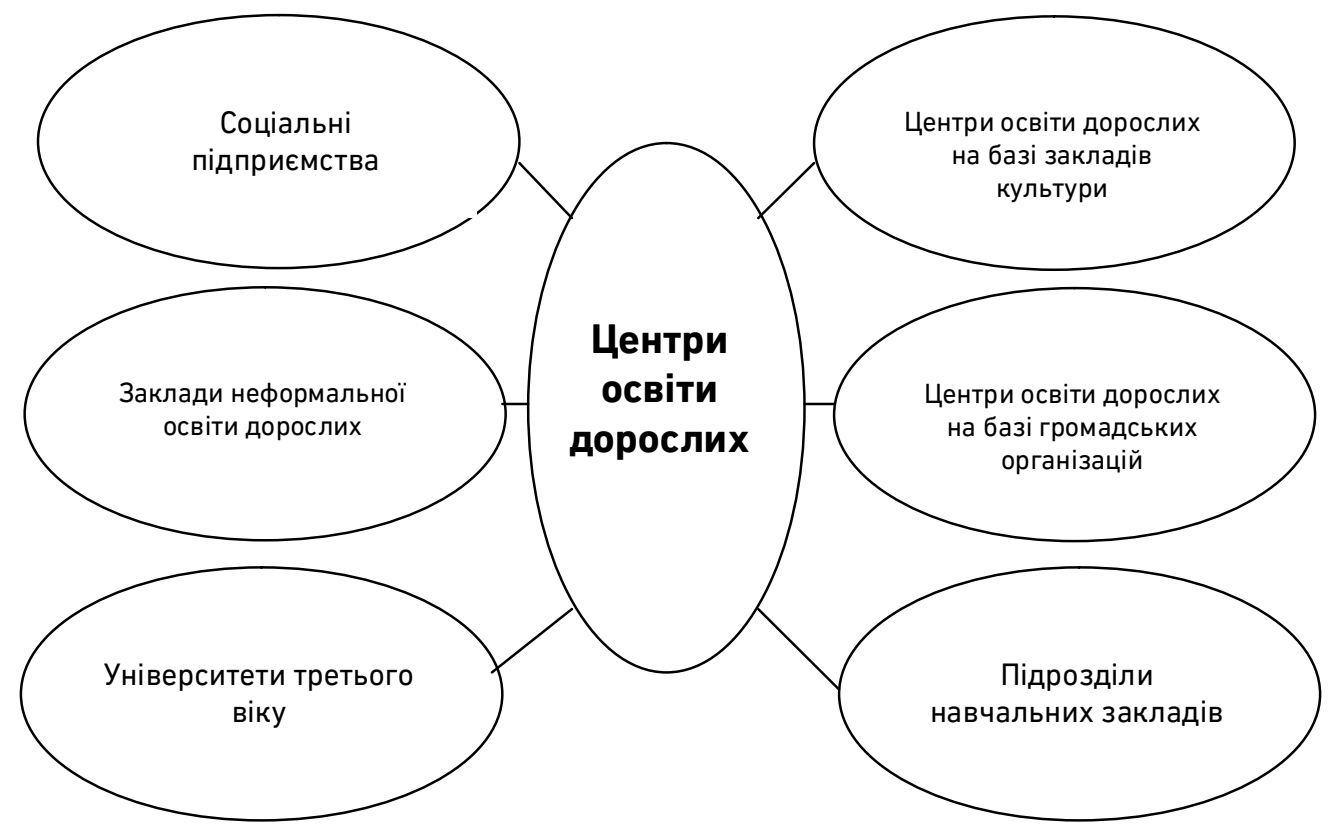

Рис. 1. Елементи інфраструктури освіти дорослих в Україні 
Значне зростання частки дорослого населення, що бере участь в різних формах навчання в рамках формальної системи освіти і за їі межами, підтверджує затребуваність зусиль щодо розвитку освіти дорослих з боку держав, міжнародних і національних організацій, неурядових структур. Освіта дорослих сьогодні $\epsilon$ важливою галуззю освіти, здатної вирішувати нагальні завдання соціальноекономічного і політичного розвитку.

Ефективним засобом розвитку системи безперервної освіти $€$ створення корпоративних університетів, які передбачають чергування базових знань з практичною діяльністю. Розвиток безперервної освіти дозволяє створити умови для формування гнучких освітніх траєкторій та вирівнювання доступу до якісної освіти на всіх рівнях освітньої системи, забезпечує комплекс освітніх послуг, що відповідають динамічному розвитку потреб особистості, суспільства та економіки.

Що стосується 3ВО, то в сучасних умовах перед ними постає проблема не просто виживання, а створення кардинально нових освітніх моделей, які будуть відповідати вимогам споживачів освітніх послуг та роботодавців; зможуть швидко адаптуватись до потреб ринку; формувати у здобувачів актуальні навички; вчити професіями, яких ще не існує. Тільки ті заклади, які знайдуть сили, інструменти, ресурси швидко змінюватися разом з мінливим запитом сучасного світу, будуть конкурентоздатними та ефективними.

В умовах сьогодення, коли щороку спостерігається катастрофічне зниження кількості вступників у ЗВО, особливо вступників на магістерський рівень підготовки, час згадати про освітній маркетинг як інструмент підвищення конкурентоздатності закладу освіти, виявлення та задоволення потреб та цінностей нових споживачів, формування стратегії розвитку на ринку освітніх послуг, стимулювання попиту на послуги навчального закладу.

Концепція неперервної освіти дає навчальним закладам можливість диверсифікувати свою діяльність, розширити цільові сегменти, асортимент освітніх послуг, форми їх надання i, зрештою, максимально комерціалізувати свою діяльність.

Крім того, особливої уваги заслуговує необхідність створення розгалуженої системи незалежного оцінювання та сертифікації знань, отриманих шляхом неформальної та інформальної освіти. Якщо людина знатиме, що результати його навчання поза формальною системою освіти можуть бути враховані і визнані, з'являється мотивація для професійного розвитку з використанням неформального та інформального навчання. Оскільки процедура обліку та визнання неформальної та інформальної освіти пов'язана $з$ 
сертифікацією компетенцій, вирішення питання про визнання результатів неформального і інформального навчання може бути пов'язано з планованим створенням мережі центрів сертифікації кваліфікацій.

До того ж, побудова системи освіти дорослих потребує нових форм супроводу та організації такого навчання - впровадження механізму наставництва, тьюторства, коучингу і консультування 3 відповідною підготовкою фахівців за цими напрямками.

Підвищену увагу необхідно приділити меті та змісту навчання, які реалізуються через вибір освітніх програм, спеціалізацій, освітніх компонент, які повинні бути актуальними для ринку праці i роботодавців.

Враховуючи вищевказані особливості навчання дорослих, існуючі недоліки в організації надання освітніх послуг, можна виділити наступні завдання, які необхідно реалізувати для формування ефективного ринку освіти дорослих в Україні (рис. 2).

\begin{tabular}{|c|}
\hline ЗАВДАННЯ ФОРМУВАННЯ РИНКУ ОСВІТИ ДОРОСЛИХ В УКРАЇНІ \\
\hline $\begin{array}{l}\text { Забезпечення механізму ефективної взаємодії та єдиного курсу для широкого кола } \\
\text { зацікавлених сторін (міністерств, місцевих органів влади, навчальних закладів, } \\
\text { організацій) }\end{array}$ \\
\hline $\begin{array}{l}\text { Удосконалення галузевої нормативно-правової бази у сфері професійної, } \\
\text { неформальної, неперервної освіти }\end{array}$ \\
\hline $\begin{array}{l}\text { Впровадження системи моніторингу та маркетингових досліджень потреб ринку праці } \\
\text { та галузей економіки }\end{array}$ \\
\hline $\begin{array}{l}\text { Оптимізація інфраструктури додаткової освіти дорослих відповідно до реальних } \\
\text { потреб в регіонах, галузях і країні в цілому }\end{array}$ \\
\hline $\begin{array}{l}\text { Удосконалення навчально-методичного, інформаційного та матеріально-технічного } \\
\text { забезпечення системи додаткової освіти дорослих на принципах СМАРТ-навчання }\end{array}$ \\
\hline $\begin{array}{l}\text { Розширення масштабів міжнародного співробітництва у сфері неперервного навчання, } \\
\text { неформальної освіти, освіти дорослих }\end{array}$ \\
\hline $\begin{array}{l}\text { Створення розгалуженої системи незалежного оцінювання та сертифікації знань, } \\
\text { отриманих шляхом неформальної та інформальної освіти }\end{array}$ \\
\hline $\begin{array}{l}\text { Розробка і впровадження інноваційних методів викладання та навчання } 3 \\
\text { урахуванням особливостей дорослої аудиторії, перегляд і адаптація навчальних планів } \\
\text { спеціальностей }\end{array}$ \\
\hline $\begin{array}{l}\text { Розвиток наставництва, тьюторства, коучингу і консультування як форм навчання } \\
\text { дорослих }\end{array}$ \\
\hline
\end{tabular}

Рис. 2. Основні завдання формування ефективного ринку освіти дорослих в Україні 
Формальна освіта дорослих може бути реалізована у вигляді магістерських програм або ліцензованих курсів за освітніми програмами навчального закладу.

Неформальна освіта має широкий вибір видів навчання і $€$ сьогодні формою здобуття освіти, якій надають перевагу саме дорослі здобувачі, виходячи 3 наступних їі переваг: краще задовольняє індивідуальні потреби здобувачів; має гнучкі можливості щодо встановлених і прийнятих процедур, цілей і змісту навчання; швидше реагує на зміни потреб ринку праці; мобільність процесу навчання; зосередження на чітко визначеній меті; забезпечує принцип неперервності освіти; дозволяє як поліпшити базові знання та навички, так і отримати нові актуальні компетенції; сприяє розвитку навичок XXI століття (креативність, критичне мислення, емоційний інтелект) тощо.

Сьогодні неформальна освіта все більше переходить до форми дистанційного або змішаного навчання. Це дозволяє навчальним закладам розширити цільовий сегмент споживачів не тільки у віковому розрізі, а і в географічному. При належній організації ефективність навчального процесу у дистанційній формі не нижча, а в деяких випадках може бути і вищою, ніж при традиційному навчанні.

Неформальна освіта може здобуватись в наступних форматах (форми організації навчального процесу): навчальні курси або програми; інтерактивні форми навчання (тренінг, воркшоп, майстерклас, семінар, вебінар); тематичні професійно-комунікативні заходи; навчання в бізнес-середовищі та ін.

Висновок. Таким чином, необхідність та перспективність реалізації реформ у сфері освіти та перехід до концепції неперервної освіти сумнівів не викликає. Особливої уваги потребує формування ефективного механізму освіти дорослих, що передбачає створення відповідної інфраструктури ринку освітніх послуг з урахуванням особливостей цього цільового сегменту, які впливають на мету, зміст, форми і методи навчання.

1. Лук'янова Л. Б. Підготовка педагогічного персоналу для роботи $з$ дорослими: теоретичний і методичний аспекти : монографія. К. : ІПООД НАПН України, 2016. 265 с. 2. Мальцев К. Особенности обучения взрослых: аксиомы обучения и развития сотрудников. URL: https://www.cfin.ru/management/people/dev_val/adult_education.shtml (дата звернення: 10.12.2020). 3. Освіта дорослих: світові тенденції, українські реалії та перспективи : монографія / Н. Г. Ничкало, Р. І. Черновол-Ткаченко, І. Ф. Прокопенко та ін. ; за заг. ред. Н. Г. Ничкало, І. Ф. Прокопенка. Ін-т педагогічної освіти і освіти дорослих ім. І. Зязюна НАПН України, Харків. нац. пед. ун-т ім. Г. С. Сковороди. Харків : Бровін О. В., 2020. 552 с. 


\section{REFERENCES:}

1. Lukianova L. B. Pidhotovka pedahohichnoho personalu dlia roboty z doroslymy: teoretychnyi i metodychnyi aspekty : monohrafiia. K. : IPOOD NAPN Ukrainy, 2016. 265 s. 2. Maltsev K. Osobennosti obucheniya vzroslyih: aksiomyi obucheniya i razvitiya sotrudnikov.

URL: https://www.cfin.ru/management/people/dev_val/adult_education.shtml (data zvernennia: 10.12.2020). 3. Osvita doroslykh: svitovi tendentsii, ukrainski realii ta perspektyvy : monohrafiia / N. H. Nychkalo, R. I. Chernovol-Tkachenko, I. F. Prokopenko ta in. ; za zah. red. N. H. Nychkalo, I. F. Prokopenka. In-t pedahohichnoi osvity i osvity doroslykh im. I. Ziaziuna NAPN Ukrainy, Kharkiv. nats. ped. un-t im. H. S. Skovorody. Kharkiv : Brovin 0. V., 2020. 552 s.

Frolenkova N. A. ${ }^{[1 ;}$ ORCID ID 0000-0003-4553-9547], Candidate of Economics (Ph.D.), Associate Professor, Stupnytska M. 0. ${ }^{[1]}$, Graduate Student

${ }^{1}$ National University of Water and Environmental Engineering, Rivne

\section{PECULIARITIES OF ADULT EDUCATION MARKET INFRASTRUCTURE FORMATION IN UKRAINE}

The authors formulated the main prerequisites for reforming the education system, in particular the introduction of the concept of continuing education and adult education. It has been established that the modern requirements of the labour market and the need to continuously acquire new competences require continuous training and development. Adult education is a separate field that provides for the educational needs of self-employed individuals. In the new economy, education will be seen as a «lifelong» process which will become a major career driver and a prerequisite for the possibility of multiple occupational scenarios throughout life. This determines the main change of today - the demand for individualization of educational trajectories. The growing diversity of cognitive and information requests of different segments of the population today can no longer be met within the existing forms of traditional education. The problem of the inadequacy of the formed education system to the new needs of society and people is growing. This requires a different approach to the organization of mass educational activities of adults - education must meet the diverse interests and capabilities of citizens. The infrastructure of the market of educational services for adults should be formed taking into account features and needs, psychophysiological characteristics, experience of applicants. The peculiarity of teaching adults is that it must be carried out 
taking into account their age, social and psychological, national and other characteristics that must be taken into account when forming the educational model of education. Educational institutions in modern conditions face the problem not just of survival, but of creating radically new educational models that will meet the requirements of consumers of educational services and employers; will be able to quickly adapt to market needs; to form relevant skills in applicants; teach professions that do not yet exist. The main tasks for the formation of the market of adult education in Ukraine are formulated.

Keywords: continuing education; adult education; infrastructure; market of educational services; tasks; features.

Фроленкова Н. А. ${ }^{[1 ; ~ O R C I D ~ i D ~ 0000-0003-4553-9547], ~}$ к.э.Н., доцент,

Ступницкая М. А. ${ }^{[1]}$, соискатель высшего образования второго (магистерского) уровня

${ }^{1}$ Национальный университет водного хозяйства и природопользования, г. Ровно

\title{
ОСОБЕННОСТИ ФОРМИРОВАНИЯ ИНФРАСТРУКТУРЫ РЫНКА ОБРАЗОВАНИЯ ВЗРОСЛЫХ В УКРАИНЕ
}

\begin{abstract}
В статье определены основные предпосылки реформирования системы образования В направлении внедрения концепции непрерывного образования и образования взрослых. Определены особенности образования взрослых, которые влияют на формирование инфраструктуры рынка образовательных услуг, выбор форм и методов обучения. Определены основные задачи по формированию рынка образования взрослых в Украине.

Ключевые слова: непрерывное образование; образование взрослых; инфраструктура; рынок образовательных услуг; задачи; особенности.
\end{abstract}

